\title{
Oznaczanie jakościowe i ilościowe (GC-FID) wybranych składników ropy naftowej
}

\begin{abstract}
Zmodyfikowano metodę GC-FID oznaczania ilościowego składników ropy naftowej. Dotychczasowa metodyka wymagała modyfikacji, w tym przede wszystkim dobrania innego rozpuszczalnika do próbek ropy naftowej. Do tej pory wykorzystywano disiarczek węgla $\left(\mathrm{CS}_{2}\right)$, który jest związkiem silnie kancerogennym, a więc jednym z powodów zmiany rozpuszczalnika były aspekty zdrowotne. Rozszerzono stosowaną metodę o analizę ilościową wybranych komponentów występujących w ropie naftowej. Opracowano analizę ilościową wybranych n-alkanów i izoalkanów oraz niskowrzących związków aromatycznych (BTX). Dobrano program temperaturowy w celu analizy standardów, które posłużyły do utworzenia krzywych kalibracyjnych. Na podstawie tychże krzywych oznaczono wybrane związki chemiczne w sposób ilościowy w około 10 ropach naftowych.
\end{abstract}

Słowa kluczowe: ropa naftowa, n-alkany, izoalkany, BTX.

\section{Qualitative and quantitative determination (GC-FID) of selected components of crude oil}

GC-FID method for the quantification of crude oil components was modified. Previous methodology required modification and a new solvent selection for oil samples. Carbon disulfide $\left(\mathrm{CS}_{2}\right)$ had been used so far and because of it's highly carcinogenic properties, the author proposed solvent replacement. The method was extended to be used for the quantitative analysis of selected components present in crude oil. Quantitative analysis of the selected n-alkane, iso-alkanes and low-boiling aromatics (BTX) was developed. A temperature program was adjusted for the analysis of standards which were used for the creation of calibration curves. Quantitative analysis of selected compounds was determined based on the curves in about 10 crude oil samples.

Key words: Crude oil, n-alkanes, isoalkanes, BTX.

\section{Podstawy teoretyczne analizy rop naftowych}

Określenie składu ropy naftowej oraz korelacji pomiędzy poszczególnymi związkami chemicznymi umożliwia poznanie geochemicznych warunków jej tworzenia, co wykorzystywane jest $\mathrm{w}$ jej poszukiwaniach i ocenie zasobów. Analiza GC-FID surowych rop naftowych pozwala na określenie charakteru rop pod kątem ich ewentualnych zmian wtórnych, czyli procesów degradacji, a także różnic w stopniu dojrzałości termicznej. Obliczane wskaźniki z takiej analizy (rysunek 1) i ich interpretację przedstawiono w tablicy 1.

Wskaźniki B, F i H używane są najczęściej jako wskaźniki termicznego przeobrażenia skał macierzystych generujących ropy. Obserwowana jest ścisła współzależność wartości wskaźników F i H ze stopniem dojrzałości ropy naftowej.
Na podstawie wartości wskaźników I i H przyjęto natomiast klasyfikację rop przytoczoną w tablicy $2[8,10]$.

W podanej klasyfikacji termin „dojrzała” oznacza, że ropa naftowa podlegała progresywnemu podgrzewaniu i znacznej transformacji termicznej (otwarcie pierścienia i skracanie łańcucha). Konwencjonalnie przyjmuje się, że tylko „dojrzałe" skały uwalniają ropę naftową. W niniejszej klasyfikacji „dojrzałe” skały uwalniają normalne, parafinowe ropy w ściśle określonym zakresie temperatur podpowierzchniowych. Normalne ropy naftowe zakumulowane w głębszych zbiornikach o wyższej temperaturze są przekształcane w ropy „dojrzałe” i „superdojrzałe” (brak wielu związków z różnych grup biomarkerów [1]). Do rop „superdojrzałych” zalicza się również ropy o ekstremalnie wysokich wartościach 
Tablica 1. Wskaźniki geochemiczne oparte na dystrybucji węglowodorów lekkich

\begin{tabular}{|c|l|l|}
\hline Symbol wskaźnika & \multicolumn{1}{|c|}{ Definicja } & \multicolumn{1}{|c|}{ Zastosowanie } \\
\hline A & benzen/n-heksan & $\begin{array}{l}\text { wskaźnik aromatyczności (frakcjonowanego } \\
\text { odparowania i wymywania wodą) }\end{array}$ \\
\hline B & toluen/n-heptan & $\begin{array}{l}\text { wskaźnik aromatyczności (frakcjonowanego } \\
\text { odparowania i wymywania wodą) }\end{array}$ \\
\hline X & ksyleny $($ m- i p-)/n-oktan & $\begin{array}{l}\text { wskaźnik aromatyczności (frakcjonowanego } \\
\text { odparowania) }\end{array}$ \\
\hline C & (n-heksan + n-heptan)/(cykloheksan + metylocykloheksan) $)$ & wskaźnik parafinowatości (dojrzałości) \\
\hline I & $\begin{array}{l}{[\text { metyloheksany }(2-\text { i 3-)]/[dimetylocyklopentany }} \\
(1 \mathrm{c} 3-, 1 \mathrm{t} 3-\text { i } 1 \mathrm{t} 2-)]\end{array}$ & wskaźnik parafinowatości (dojrzałości) \\
\hline F & n-heptan/metylocykloheksan & $\begin{array}{l}\text { wskaźnik parafinowatości (dojrzałości } \\
\text { i wymywania wodą) }\end{array}$ \\
\hline H & $100 \times$ n-heptan/(cykloheksan $+\ldots+$ metylocykloheksan) ${ }^{*}$ & wskaźnik parafinowatości (dojrzałości) \\
\hline
\end{tabular}

$($ cykloheksan $+\ldots+$ metylocykloheksan $)=($ cykloheksan +2 -metyloheksan +1 1-dimetylocyklopentan +3 -metyloheksan +1 -cis-3dimetylocyklopentan +1 -trans-3-dimetylocyklopentan +1 -trans-2-dimetylocyklopentan + n-heptan + metylocykloheksan) $\mathrm{z}$ wyłączeniem 1-cis-2dimetylocyklopentanu

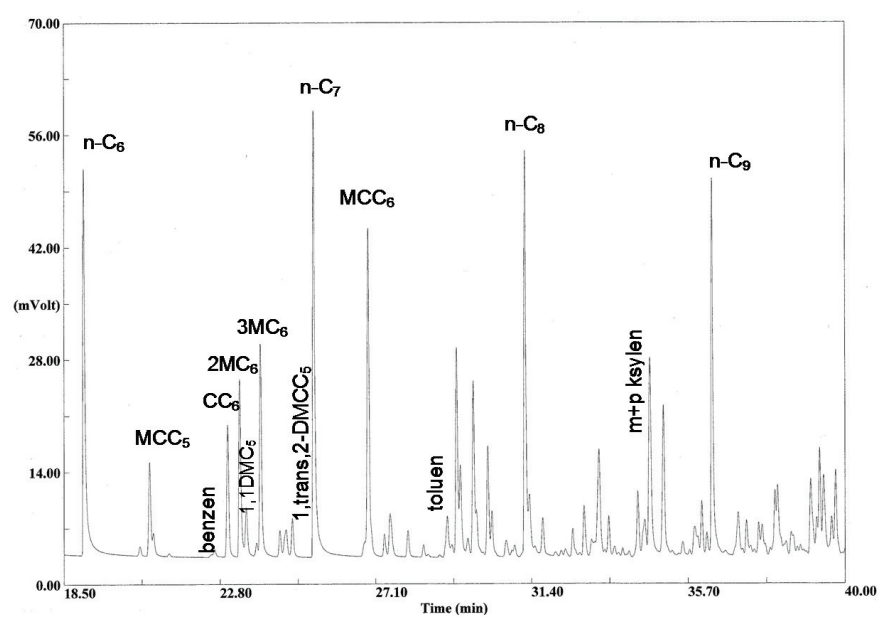

Rys. 1. Skład węglowodorów w przykładowej surowej ropie w zakresie lekkich węglowodorów do n- $\mathrm{C}_{10}$

wskaźników H i I. Powstają one w efekcie długotrwałej termicznej transformacji.

Wskaźniki zawarte w tablicy 1 służą również do określenia wpływu procesów wtórnych (wymywanie wodą, biodegradacja) na skład chemiczny rop naftowych, a tym samym do określenia stopnia degradacji. Procesowi wymywania wodą towarzyszy ubytek niżejcząsteczkowych węglowodorów aromatycznych (benzen, toluen, ksyleny), co powoduje obniżenie wartości wskaźników A, B i X. Ewaporatowa frakcjonacja wpływa na wartości wskaźników B i F, dając w przypadku rop $\mathrm{B}>1$, a $\mathrm{F}<0,5$ [9]. Odwrotną zależność obserwuje się dla kondensatów i gazów [6].

Oznaczenie ilościowe wybranych niskowrzacych składników ropy naftowej jest pomocne w interpretacji pod kątem poszukiwawczym. Pozwala ono również na poszerzenie zakresu analizowanych typów próbek o produkty przeróbki technologicznej ropy naftowej (benzyna, olej napędowy).

Tablica 2. Klasyfikacja rop naftowych na podstawie wskaźnika heptanowego i izoheptanowego [8]

\begin{tabular}{|l|c|c|}
\hline \multicolumn{1}{|c|}{ Ropa naftowa } & $\begin{array}{c}\text { Wskaźnik } \\
\text { heptanowy }(\mathrm{H})\end{array}$ & $\begin{array}{c}\text { Wskaźnik } \\
\text { izoheptanowy (I) }\end{array}$ \\
\hline Normalna, parafinowa & $12 \div 22$ & $0,8 \div 1,2$ \\
\hline Dojrzała & $22 \div 30$ & $1,2 \div 2,0$ \\
\hline Superdojrzała & $30 \div 60$ & $2,0 \div 4,0$ \\
\hline Zbiodegradowana & $0 \div 18$ & $0,0 \div 0,8$ \\
\hline
\end{tabular}

\section{Metodyka badań}

Analiza chromatograficzna zarówno standardów, jak i próbek surowych rop naftowych została przeprowadzona przy użyciu chromatografu Trace GC Ultra firmy Thermo. Oznaczenia wykonano z wykorzystaniem kolumny Rtx-1 (długość - 105 m, średnica - 0,32 mm, grubość filmu - $1 \mu \mathrm{m}$ ) i detektora FID. Dobrano inny rozpuszczalnik - n-pentan, który zastąpił dotychczas stosowany disiarczek węgla $\left(\mathrm{CS}_{2}\right)$. Używano następujących programów temperaturowych do analizy zarówno standardu, jak i rzeczywistych próbek rop naftowych:
Program temperaturowy dla standardu:

- temperatura początkowa: $33^{\circ} \mathrm{C}$,

- izoterma w temperaturze początkowej: 8 minut,

- narost temperatury: $4^{\circ} \mathrm{C} / \mathrm{min}$,

- temperatura końcowa: $160^{\circ} \mathrm{C}$.

Program temperaturowy dla próbek rop naftowych:

- temperatura początkowa: $33^{\circ} \mathrm{C}$,

- izoterma w temperaturze początkowej: 8 minut,

- narost temperatury: $4^{\circ} \mathrm{C} / \mathrm{min}$, 
- temperatura pośrednia: $210^{\circ} \mathrm{C}$,

- narost temperatury: $3^{\circ} \mathrm{C} / \mathrm{min}$,

- temperatura końcowa: $310^{\circ} \mathrm{C}$,

- izoterma w temperaturze końcowej: $27 \mathrm{~min}$.

Warunki pracy chromatografu (nastrzyk $-1 \mu 1$, podział strumienia -30 , temperatura detektora $-310^{\circ} \mathrm{C}$, przepływ gazu nośnego - $1 \mathrm{ml} / \mathrm{min}$ ) i rozpuszczalnik zostały dobrane w taki sposób, że piki są strzeliste, dobrze rozdzielone [7].

Używano standardu o składzie: n-heptan $\left(n-C_{7}\right)$, n-oktan $\left(n-C_{8}\right)$, benzen, toluen, ksyleny (meta- i para-), cykloheksan $\left(\mathrm{CC}_{6}\right)$ i metylocykloheksan $\left(\mathrm{MCC}_{6}\right)$. Powyższe związki chemiczne były rozpuszczone w n-pentanie. W celu wykonania krzywych kalibracyjnych sporządzono roztwory o powyższym składzie i następujących stężeniach każdego składnika: 1 vppm, 10 vppm, 50 vppm, 100 vppm, 250 vppm, 500 vppm i 1000 vppm. Każdy standard został poddany analizie na chromatografie GC dwukrotnie. Przykładowy chromatogram przedstawiający analizę standardu pokazano na rysunku 2. Następnie wykonano krzywe kalibracyjne opierające się aż na 7 punktach (7 różnych stężeń standardu), a dokładnie będące średnią z oznaczania dwóch standardów o takim samym stężeniu. Odpowiedź detektora nie jest liniowa. Krzywe kalibracyjne są funkcjami nieliniowymi i w takim przypadku ich dopasowanie do całego zakresu wyznaczanych stężeń jest najdokładniejsze [4].

Do analiz rop naftowych wystarczający jest zakres stężeń od 1 vppm do 1000 vppm. Ze względu na brak wyraźnego rozdziału (na stosowanej kolumnie) metaksylenu od paraksylenu zrezygnowano z oznaczania ilości tych związków podczas walidacji metody.

W celu określenia dokładności metody sporządzono łącznie dwanaście roztworów o stężeniach: 1 vppm, 10 vppm, 50 vppm i 500 vppm każdego ze składników. Wykonywa-

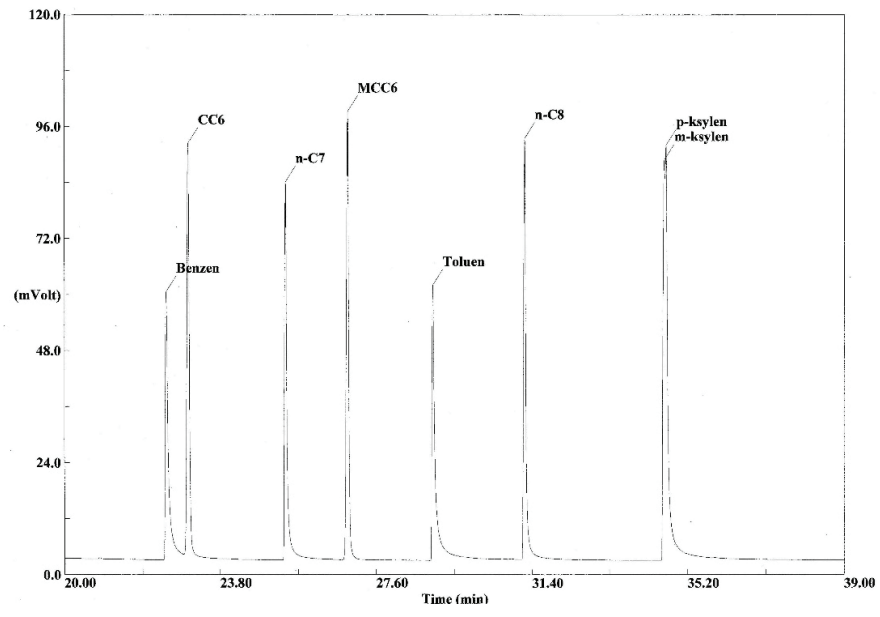

Rys. 2. Chromatogram standardu o stężeniu 500 vppm każdego ze składników

no po trzy analizy każdego roztworu. Mieszanka do każdej analizy była przygotowywana bezpośrednio przed badaniem.

Dla każdego stężenia policzono: średnią arytmetyczną, odchylenie standardowe, względne odchylenie standardowe, a także granice przedziałów (tablice 3-8). Wartość rzeczywista, czyli wartość standardu (1 vppm, 10 vppm, 50 vppm i 500 vppm), musi się zawierać w przedziale:

$$
\mu_{x} \in(\bar{x}-2 \cdot s ; \bar{x}+2 \cdot s)
$$

gdzie:

$\mu_{x}-$ wartość rzeczywista,

$\bar{x}$ - średnia arytmetyczna,

$s$ - odchylenie standardowe.

Jeżeli wartość rzeczywista nie zawiera się w przedziale, metoda obarczona jest błędem $[3,11]$.

\section{Elementy walidacji metody}

Wartości rzeczywiste dla roztworu o stężeniu 1 vppm nie znajdują się w wyznaczonym przedziale. Dokładność na poziomie 1 vppm jest obarczona dużym błędem, dlatego uznano, że wyniki na tym poziomie nie są wiarygodne i dolna granica zakresu stosowania metody została wyznaczona na wartość 10 vppm. Na poziomie 10 vppm i 50 vppm wyniki są zadowalające, jedynie cykloheksan na poziomie $50 \mathrm{vppm}$ jest obarczony błędem (jego wartość jest zawyżona). W tym przypadku należy korygować wyniki. Na poziomie 500 vppm wartości rzeczywiste wszystkich oznaczanych składników mieszczą się w wyznaczonych przedziałach.

Następnym krokiem walidacyjnym było określenie powtarzalności metody $[2,5]$. W tym celu sporządzano roztwory o stężeniu 250 ppm każdego ze składników (każdorazowo przed analizą chromatograficzną). Operacja ta zosta- ła powtórzona sześciokrotnie. Po uzyskaniu danych z analiz (tablica 9) obliczono średnią arytmetyczną, odchylenie standardowe oraz względne odchylenie standardowe (tablica 10).

Względne odchylenia standardowe w przypadku benzenu i n-heptanu są do zaakceptowania (RSD [\%] nie powinno przekraczać 5\%, dla śladowych stężeń: 15\%) [5]. Wartości względnych odchyleń standardowych dla cykloheksanu, metylocykloheksanu, toluenu i n-oktanu są nieco wyższe. W tych przypadkach w celu określenia powtarzalności lepiej jest skorzystać ze średnich arytmetycznych ze względnych odchyleń standardowych serii badań poszczególnych roztworów, wykonywanych podczas wyznaczania dokładności metody (tablica 11).

Z uwagi na użycie krzywych kalibracyjnych granice oznaczalności i wykrywalności nie zostały wyznaczone przy po- 
mocy wielokrotnego badania ślepej próbki. Z reguły minimalna wartość, dla jakiej można stosować krzywą kalibracyjną, to $90 \%$ najmniejszego stężenia użytego do wykreślania krzy- wej, natomiast maksymalna wartość to $110 \%$ największego. W przypadku omawianej metody wartość minimalna, dla której stosowano krzywą kalibracyjną, to $90 \%$ stężenia $10 \mathrm{vppm}$.

Tablica 3. Zawartości badanych związków w trzech kolejnych roztworach o stężeniach 500 vppm (każdy składnik)

\begin{tabular}{|l|c|c|c|}
\hline \multicolumn{1}{|c|}{ Związek chemiczny } & $500 \mathrm{vppm}$ & $500 \mathrm{vppm}$ & $500 \mathrm{vppm}$ \\
\hline Benzen & 442,1 & 486,2 & 477,7 \\
\hline Cykloheksan & 461,5 & 505,6 & 467,9 \\
\hline n-heptan & 480,7 & 503,7 & 450,0 \\
\hline Metylocykloheksan & 485,8 & 508,2 & 453,0 \\
\hline Toluen & 444,3 & 472,4 & 470,6 \\
\hline n-oktan & 490,6 & 538,1 & 525,5 \\
\hline
\end{tabular}

Tablica 4. Wartości parametrów statystycznych roztworów o stężeniach 500 vppm każdego ze składników

\begin{tabular}{|l|c|c|c|c|c|}
\hline \multicolumn{1}{|c|}{$500 \mathrm{vppm}$} & $\begin{array}{c}\text { Średnia } \\
\text { arytmetyczna } \\
(\text { Xśr) }\end{array}$ & $\begin{array}{c}\text { Odchylenie } \\
\text { standardowe } \\
(\mathrm{s})\end{array}$ & $\begin{array}{c}\text { Względne odchylenie } \\
\text { standardowe } \\
(\text { RSD) }\end{array}$ & $\begin{array}{c}\text { Dolna granica } \\
\text { przedziału }\end{array}$ & $\begin{array}{c}\text { Górna granica } \\
\text { przedziału }\end{array}$ \\
\hline Benzen & 468,7 & 23,4 & 5,0 & 421,9 & 515,5 \\
\hline Cykloheksan & 478,3 & 23,8 & 5,0 & 430,7 & 526,0 \\
\hline n-heptan & 478,1 & 26,9 & 5,6 & 424,2 & 532,0 \\
\hline Metylocykloheksan & 482,3 & 27,8 & 5,8 & 426,8 & 537,9 \\
\hline Toluen & 462,4 & 15,7 & 3,4 & 431,0 & 493,9 \\
\hline n-oktan & 518,1 & 24,6 & 4,7 & 468,9 & 567,3 \\
\hline
\end{tabular}

Tablica 5. Zawartości badanych związków w trzech kolejnych roztworach o stężeniach 50 vppm (każdy składnik)

\begin{tabular}{|l|c|c|c|}
\hline \multicolumn{1}{|c|}{ Związek chemiczny } & $50 \mathrm{vppm}$ & $50 \mathrm{vppm}$ & $50 \mathrm{vppm}$ \\
\hline Benzen & 57,1 & 59,6 & 53,1 \\
\hline Cykloheksan & 61,3 & 62,9 & 61,1 \\
\hline n-heptan & 54,9 & 56,2 & 51,6 \\
\hline Metylocykloheksan & 59,5 & 57,1 & 53,6 \\
\hline Toluen & 47,9 & 48,3 & 50,3 \\
\hline n-oktan & 57,6 & 52,7 & 54,5 \\
\hline
\end{tabular}

Tablica 6. Wartości parametrów statystycznych roztworów o stężeniach 50 vppm każdego ze składników

\begin{tabular}{|l|c|c|c|c|c|}
\hline \multicolumn{1}{|c|}{$50 \mathrm{vppm}$} & $\begin{array}{c}\text { Średnia } \\
\text { arytmetyczna } \\
(\text { Xśr) }\end{array}$ & $\begin{array}{c}\text { Odchylenie } \\
\text { standardowe } \\
(\mathrm{s})\end{array}$ & $\begin{array}{c}\text { Względne odchylenie } \\
\text { standardowe } \\
(\text { RSD) }\end{array}$ & $\begin{array}{c}\text { Dolna granica } \\
\text { przedziału }\end{array}$ & $\begin{array}{c}\text { Górna granica } \\
\text { przedziału }\end{array}$ \\
\hline Benzen & 56,6 & 3,3 & 5,8 & 50,0 & 63,2 \\
\hline Cykloheksan & 61,8 & 1,0 & 1,6 & 59,8 & 63,7 \\
\hline n-heptan & 54,2 & 2,4 & 4,4 & 49,5 & 59,0 \\
\hline Metylocykloheksan & 56,7 & 3,0 & 5,2 & 50,8 & 62,7 \\
\hline Toluen & 48,8 & 1,3 & 2,6 & 46,3 & 51,4 \\
\hline n-oktan & 54,9 & 2,5 & 4,5 & 50,0 & 59,9 \\
\hline
\end{tabular}


Tablica 7. Zawartości badanych związków w trzech kolejnych roztworach o stężeniach 10 vppm (każdy składnik)

\begin{tabular}{|l|c|c|c|}
\hline \multicolumn{1}{|c|}{ Związek chemiczny } & $10 \mathrm{vppm}$ & $10 \mathrm{vppm}$ & $10 \mathrm{vppm}$ \\
\hline Benzen & 9,4 & 9,0 & 10,0 \\
\hline Cykloheksan & 8,9 & 10,0 & 9,4 \\
\hline n-heptan & 8,7 & 9,5 & 9,3 \\
\hline Metylocykloheksan & 9,2 & 10,1 & 9,6 \\
\hline Toluen & 9,9 & 10,9 & 10,2 \\
\hline n-oktan & 9,8 & 10,8 & 10,1 \\
\hline
\end{tabular}

Tablica 8. Wartości parametrów statystycznych roztworów o stężeniach 10 vppm każdego ze składników

\begin{tabular}{|l|c|c|c|c|c|}
\hline \multicolumn{1}{|c|}{$10 \mathrm{vppm}$} & $\begin{array}{c}\text { Średnia } \\
\text { arytmetyczna } \\
(\text { Xśr) }\end{array}$ & $\begin{array}{c}\text { Odchylenie } \\
\text { standardowe } \\
(\mathrm{s})\end{array}$ & $\begin{array}{c}\text { Względne odchylenie } \\
\text { standardowe } \\
(\text { RSD) }\end{array}$ & $\begin{array}{c}\text { Dolna granica } \\
\text { przedziału }\end{array}$ & $\begin{array}{c}\text { Górna granica } \\
\text { przedziału }\end{array}$ \\
\hline Benzen & 9,5 & 0,5 & 5,3 & 8,5 & 10,5 \\
\hline Cykloheksan & 9,4 & 0,6 & 5,8 & 8,3 & 10,5 \\
\hline n-heptan & 9,2 & 0,4 & 4,5 & 8,3 & 10,0 \\
\hline Metylocykloheksan & 9,6 & 0,5 & 4,7 & 8,7 & 10,5 \\
\hline Toluen & 10,3 & 0,5 & 5,0 & 9,3 & 11,4 \\
\hline n-oktan & 10,2 & 0,5 & 5,0 & 9,2 & 11,3 \\
\hline
\end{tabular}

Tablica 9. Zawartości badanych związków w sześciu kolejnych roztworach o stężeniach 250 vppm (każdy składnik)

\begin{tabular}{|l|c|c|c|c|c|c|}
\hline Związek chemiczny & $250 \mathrm{vppm}$ & $250 \mathrm{vppm}$ & $250 \mathrm{vppm}$ & $250 \mathrm{vppm}$ & $250 \mathrm{vppm}$ & $250 \mathrm{vppm}$ \\
\hline Benzen & 237,4 & 230,9 & 240,1 & 254,3 & 257,3 & 233,5 \\
\hline Cykloheksan & 239,3 & 225,9 & 246,5 & 229,5 & 258,2 & 259,9 \\
\hline n-heptan & 238,3 & 217,7 & 234,7 & 246,3 & 238,5 & 249,0 \\
\hline Metylocykloheksan & 238,8 & 220,0 & 264,6 & 254,9 & 243,7 & 247,4 \\
\hline Toluen & 228,9 & 209,5 & 229,0 & 258,9 & 233,5 & 225,2 \\
\hline n-oktan & 240,9 & 213,9 & 219,5 & 270,3 & 247,5 & 239,0 \\
\hline
\end{tabular}

Tablica 10. Wartości parametrów statystycznych sześciu roztworów o stężeniach 250 vppm (każdy ze składników)

\begin{tabular}{|l|c|c|c|}
\hline \multicolumn{1}{|c|}{$250 \mathrm{vppm}$} & $\begin{array}{c}\text { Średnia arytmetyczna } \\
\text { (Xśr) }\end{array}$ & $\begin{array}{c}\text { Odchylenie standardowe } \\
(\mathrm{s})\end{array}$ & $\begin{array}{c}\text { Względne odchylenie standardowe } \\
\text { (RSD) }\end{array}$ \\
\hline Benzen & 242,3 & 11,0 & 4,5 \\
\hline Cykloheksan & 243,2 & 14,3 & 5,9 \\
\hline n-heptan & 237,4 & 11,1 & 4,7 \\
\hline Metylocykloheksan & 244,9 & 15,2 & 6,2 \\
\hline Toluen & 230,8 & 16,1 & 7,0 \\
\hline n-oktan & 238,5 & 20,3 & 8,5 \\
\hline
\end{tabular}

Tablica 11. Względne odchylenia standardowe obliczone z pomiaru dokładności oraz ich średnie arytmetyczne

\begin{tabular}{|l|c|c|c|c|}
\hline \multirow{2}{*}{ Związek } & \multicolumn{3}{|c|}{ Względne odchylenie standardowe } & Średnie względne odchylenie \\
\cline { 2 - 4 } & $500 \mathrm{vppm}$ & $50 \mathrm{vppm}$ & $10 \mathrm{vppm}$ & 4,1 \\
\hline Cykloheksan & 5,0 & 1,6 & 5,8 & 5,2 \\
\hline Metylocykloheksan & 5,8 & 5,2 & 4,7 & 3,7 \\
\hline Toluen & 3,4 & 2,6 & 5,0 & 4,7 \\
\hline n-oktan & 4,7 & 4,5 & 5,0 & \\
\hline
\end{tabular}




\section{Analiza rop naftowych}

Po wykonaniu walidacji wybrano około 10 próbek rop naftowych, przy użyciu których postanowiono sprawdzić opracowaną metodę oznaczania wybranych składników. Ropy naftowe pochodziły z syneklizy perybałtyckiej oraz z Karpat.
W tablicy 12 podano wartości oznaczanych składników w przykładowych ropach naftowych. W dwóch przypadkach (ropy naftowe z Dukli i Niebieszczan) benzen jest poniżej granicy oznaczalności. W przypadku ropy naftowej B5 n-heptan znajduje się powyżej granicy oznaczalności.

Tablica 12. Zawartości oznaczanych składników w próbkach rop naftowych

\begin{tabular}{|l|c|c|c|c|c|c|}
\hline \multicolumn{1}{|c|}{ Próbka } & Benzen & $\mathrm{CC}_{6}$ & $\mathrm{n}-\mathrm{C}_{7}$ & $\mathrm{MCC}_{6}$ & Toluen & $\mathrm{n}-\mathrm{C}_{8}$ \\
\hline B1 & 9,8 & 73,8 & 294,3 & 185,3 & 32,1 & 221,4 \\
\hline B2 & 9,1 & 55,0 & 267,0 & 131,8 & 27,0 & 176,5 \\
\hline B3 & 8,8 & 56,8 & 282,6 & 135,4 & 28,9 & 220,3 \\
\hline B4 & 8,6 & 54,5 & 254,0 & 140,0 & 25,3 & 184,5 \\
\hline B5 & 13,0 & 110,3 & $>1000,0$ & 454,4 & 74,1 & 828,0 \\
\hline B6 & 12,7 & 122,5 & 612,8 & 323,9 & 48,4 & 461,8 \\
\hline Dukla-1 & $<9,0$ & 117,8 & 163,6 & 299,6 & 17,0 & 128,2 \\
\hline Niebieszczany-1 & $<9,0$ & 141,9 & 164,5 & 605,0 & 28,3 & 139,4 \\
\hline
\end{tabular}

\section{Podsumowanie}

Opracowano metodę oznaczania ilościowego wybranych składników rop naftowych. Zmodyfikowano również analizę jakościową - zmieniono rozpuszczalnik, dobrano nowe parametry pracy chromatografu, m.in. program temperaturowy pieca, i uzyskano zadowalające rezultaty, jeśli chodzi o rozdział pików i czułość analizy.

Przeprowadzona walidacja potwierdziła dokładność metody w zakresie stężeń od 10 vppm do 1000 vppm. Zakładany zakres oznaczanych stężeń miał mieć wartość minimalną równą $1 \mathrm{vppm}$, jednak ponieważ na poziomie tego stężenia oznaczane wartości obarczone były błędem, dlatego za dolną granicę zakresu stosowania metody uznano wartość 10 vppm. Na tym poziomie dokładność pomiaru jest bardzo dobra.

Proces walidacji potwierdził również powtarzalność me- tody dla oznaczanych składników (najlepsza powtarzalność w przypadku benzenu i n-heptanu).

W końcowym etapie pracy wybrano około 10 próbek rop naftowych, przy użyciu których sprawdzono praktycznie opracowaną metodę oznaczania wybranych składników w ropach naftowych.

Przedstawiona metoda poszerza możliwości w analizie rop naftowych oraz stwarza podstawy do analizy produktów przeróbki technologicznej ropy naftowej.

W przyszłości można rozszerzyć metodę o możliwość oznaczania zawartości wybranych związków występujących na poziomie poniżej 10 vppm, jak również dobrać nowe związki chemiczne, dla których przeprowadzałoby się oznaczenia ilościowe.

Prosimy cytować jako: Nafta-Gaz 2016, nr 12, s. 1028-1024, DOI: 10.18668/NG.2016.12.03

Artykuł nadesłano do Redakcji 22.03.2016 r. Zatwierdzono do druku 2.12.2016 r.

Artykuł powstał na podstawie pracy statutowej pt. Opracowanie metodyki oznaczania ilościowego (GC-FID) wybranych składników surowej ropy naftowej - praca INiG - PIB na zlecenie MNISW; numer zlecenia: 74/SG/2015, numer archiwalny: DK-4100-74/15.

\section{Literatura}

[1] Bieleń W., Matyasik I.: Ropy naftowe i ekstrakty bituminów o niskiej zawartości biomarkerów - preparatyka próbek przeznaczonych do analizy GC-MS. Nafta-Gaz 2014, nr 12, s. $868-873$.

[2] Holewa J., Szlęk M.: Wpływ parametrów metody analitycznej na powtarzalność wyznaczonych na jej podstawie właściwości fizykochemicznych gazu, na przykładzie ciepła spalania. Nafta-Gaz 2014, nr 7, s. 439-443.

[3] Jakubowska M.: Walidacja metod analitycznych. Prezentacja
Katedry Chemii Analitycznej Wydziału Inżynierii Materiałowej i Ceramiki Akademii Górniczo-Hutniczej im. St. Staszica w Krakowie.

[4] Kania M., Janiga M.: Elementy walidacji metody analitycznej oznaczania w mieszaninie gazowej związów węglowodorowych oraz $\mathrm{N}_{2}, \mathrm{O}_{2}$, CO i $\mathrm{CO}_{2}$ za pomoca dwukanatowego, zaworowego chromatografu gazowego AGILENT 7890 A. Nafta-Gaz 2011, nr 11, s. 812-824.

[5] Kania M., Janiga M.: Wykorzystanie pirolitycznej chromato- 
grafii gazowej do określania składu produktów symulowanego procesu generowania węglowodorów. Nafta-Gaz 2015, nr 10, s. 720-728, DOI: 10.18668/NG2015.10.02.

[6] Odden W., Pateince R.L., Grass G.W.: Application of light hydrocarbons $\left(C_{4}-C_{13}\right)$ to oil/source rock correlations. A study of light hydrocarbon compositions of source rocks and test fluids from offshore Mid-Norway. Organic Geochemistry 1998 , vol. 28 , no. 12 , s. 823-847.

[7] Onojake M.C., Osuji L.C., Oforka N.C.: Preliminary hydrocarbon analysis of crude oils from Umutu/Bomu fields, south west Niger Delta Nigeria. Egyptian Journal of Petroleum 2013, vol. 22, no. 2, s. 217-224.

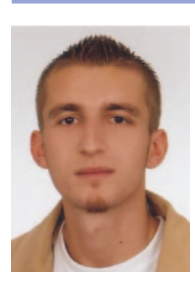

Mgr inż. Wojciech BIELEŃ

Starszy specjalista badawczo-techniczny w Zakładzie Geologii i Geochemii.

Instytut Nafty i Gazu - Państwowy Instytut Badawczy

ul. Lubicz 25 A

31-503 Kraków

E-mail: wojciech.bielen@inig.pl
[8] Thompson K.F.M.: Classification and thermal history of petroleum based on light hydrocarbons. Geochimica et Cosmochimica Acta 1983, vol. 47, no. 2, s. 303-316.

[9] Thompson K.F.M.: Fractionated aromatic petroleums and the generation of gas-condensates. Organic Geochemistry 1987, vol. 11, no. 6, s. 573-590.

[10] Wang P., Xu G., Xiao T., Zhang D., Zhang B.: Application of $C_{5}-C_{13}$ light hydrocarbons in depositional environment diagnosis. Progress in Natural Science: Materials International 2008, vol. 18, no. 9, s. 1129-1137.

[11] Wyrażanie niepewności pomiaru. Wydawnictwo GUM - dokument EA-4/02 1999.

\section{OFERTA}

\section{ZAKŁAD GEOLOGII I GEOCHEMII}

Zakres działania:

- analiza systemów naftowych (badania skał macierzystych, modelowanie generacji, ekspulsji i migracji węglowodorów, analiza dróg migracji, analiza parametrów zbiornikowych pułapek złożowych);

- badania prospekcyjne (trendy przestrzennego rozwoju parametrów zbiornikowych i filtracyjnych, analiza macierzystości, ranking stref zbiornikowych);

- $\quad$ konstrukcja statycznych modeli geologiczno-złożowych 3D;

- analiza procesów diagenetycznych i ich wpływu na parametry zbiornikowe skał;

- genetyczna korelacja płynów złożowych ze skałami macierzystymi;

- obliczanie zasobów złóż węglowodorów z analizą niepewności;

- $\quad$ modele przepływu płynów złożowych w skałach zbiornikowych;

- badania ekshalacji gazu;

- badania złóż typu tight/shale gas;

- $\quad$ specjalistyczne analizy: przestrzeni porowej, petrograficzne, geochemiczne RSO, płynów złożowych, analizy: biomarkerów, chromatograficzne, GC/MS, GC/MS/MS, składu izotopowego GC-IRMS

- $\quad$ interpretacja danych geofizyki wiertniczej.

Telefon: 126177687

Faks: 124303885

E-mail: grzegorz.lesniak@inig.pl 